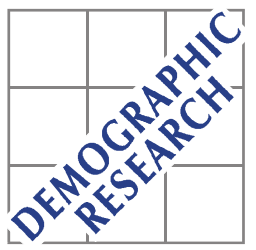

Demographic Research a free, expedited, online journal of peer-reviewed research and commentary in the population sciences published by the Max Planck Institute for Demographic Research Konrad-Zuse Str. 1, D-18057 Rostock · GERMANY www.demographic-research.org

DEMOGRAPHIC RESEARCH

VOLUME 23, ARTICLE 10, PAGES 257-292

PUBLISHED 03 AUGUST 2010

http://www.demographic-research.org/Volumes/Vol23/10/

DOI: 10.4054/DemRes.2010.23.10

Review Article

\title{
A review of the antecedents of union dissolution
}

\section{Torkild Hovde Lyngstad}

\section{Marika Jalovaara}

(C) 2010 Torkild Hovde Lyngstad \& Marika Jalovaara.

This open-access work is published under the terms of the Creative Commons Attribution NonCommercial License 2.0 Germany, which permits use, reproduction \& distribution in any medium for non-commercial purposes, provided the original author(s) and source are given credit. See http:// creativecommons.org/licenses/by-nc/2.0/de/ 


\section{Table of Contents}

1 Introduction $\quad 258$

2 Age, period, and cohort $\quad 259$

3 Union type, union order, and same-sex unions 260

4 Children 262

$5 \quad$ Educational attainment 264

$6 \quad$ Employment and income $\quad 265$

$7 \quad$ Gender perspectives, values, and religiosity 268

$8 \quad$ Migration and minority status $\quad 269$

9 Intergenerational transmission processes $\quad 270$

$\begin{array}{lll}10 & \text { Biological and health-related factors } & 271\end{array}$

11 Contextual factors $\quad 272$

$12 \quad$ National divorce legislation 273

$\begin{array}{lll}13 & \text { Conclusions } & 274\end{array}$

14 Acknowledgements 275

$\begin{array}{ll}\text { References } & 276\end{array}$ 


\title{
A review of the antecedents of union dissolution
}

\author{
Torkild Hovde Lyngstad ${ }^{1}$ \\ Marika Jalovaara ${ }^{2}$
}

\begin{abstract}
The question of what factors contribute to the stability of coresidential partnerships has attracted the attention of many social scientists. This study summarizes recent research on the determinants of union dissolution within a set of substantive themes. Special emphasis is placed on the past two decades of research. European as well as American contributions are considered.
\end{abstract}

${ }^{1}$ Corresponding author: Torkild H. Lyngstad, Department of Sociology and Human Geography, University of Oslo, PO Box 1096 Blindern, 0317 OSLO, Norway. E-mail: t.h.lyngstad@sosgeo.uio.no.

${ }^{2}$ Department of Social Research, University of Helsinki. 


\section{Introduction}

In this paper, we offer a brief review of research into the social, demographic, and economic factors that contribute to the dissolution of coresidential relationships. In contemporary industrialized societies, the break-up of a coresidential relationship is an increasingly common life course event (Andersson and Philipov 2002), and it is consequential both for adults and children (Amato 2000).

Our focus is chiefly on demographic research on antecedents of separation (moving apart) and divorce. While many of the studies to date have concentrated on the dissolution of marriages rather than of cohabiting unions - mainly because there is less data on unmarried couples who live together - a larger body of literature on cohabiting unions is emerging. A related line of research focusing on more subjective and psychological factors, such as union quality and marital interactions, will not be summarized in this paper. Very good reviews of these research areas are available (Bradbury, Fincham, and Beach 2000; Gottman and Notarius 2000). Moreover, the present summary is, for the most part, restricted to studies published in international peer-reviewed journals.

The most recent article that provided a broad summary of dissolution determinants covered the period up to the year 1990, and focused on American contributions (White 1990). Indeed, much of what we then knew about factors that influence the propensity to divorce was based on American research. In recent decades, research on the antecedents of union dissolution has expanded significantly, especially in Europe. We exclude studies that primarily relate to less developed countries.

Most of this research is, either explicitly or implicitly, based on a micro-level theory of individual choice and couple-level bargaining. The early work by Gary Becker and colleagues (Becker, Landes, and Michael 1977) assumed a unitary household utility function, while later economic theory has more explicitly acknowledged that men and women may have differing incentives/disincentives (Lundberg and Pollak 1996). Meanwhile, sociologists have formulated theories explicitly including structural and cultural constraints (Levinger 1976, Brines and Joyner 1999, South, Trent, and Shen 2001). Whether it is completely tacit or it is formulated in terms of either microeconomics or rational actor-based sociology, there seems to be an agreement that the dissolution process involves some variant of utility maximization. This has been called the utilitarian synthesis by Brines and Joyner (1999). To augment the idea of utility maximization, various additional theoretical ideas have been invoked by researchers. These ideas connect the partners with, for example, their childhood experiences, their own union and childbearing histories, the resources brought into the partnership, their integration into labour markets, the organization of domestic life, and the social surroundings. 
The paper is organized in sections, with each covering one strand of research on factors related to union dissolution. In some subfields, there is plenty of research; whereas in others, our knowledge is rather sparse. A brief conclusion also comments on trends in union dissolution research.

\section{Age, period, and cohort}

The basic time dimensions of union dissolution-namely, the spouses' ages, the duration of their union, the period, and the union cohort (the time the partners moved in together or married) - were given more attention in the 1980s than they are now.

The increase in divorce risk over (historical) time can be a cohort-driven phenomenon: different cohorts may bring, for example, different experiences, resources, and expectations to their unions, and these differences may translate into higher divorce risks for younger cohorts. But the increase can also be a period-driven phenomenon, in which the same social forces affect various cohorts at the same time. An example of the latter would be that, because the normative constraints on divorce weaken over time, the risk of divorce tends to also increase for those who have entered their union under a more restrictive normative climate. Research from both Finland (Lutz, Wils, and Nieminen 1991) and the United States (Teachman 2002) suggests that the effect of period strongly dominates the effect of marriage cohort. One American study has, however, found a cohort effect, net of period, by controlling for macro-social indicators, such as women's educational attainment (Ono 1999).

Age at marriage is consistently found to have a strong impact on the propensity to separate or divorce, with lower ages at marriage being associated with higher risks of marital disruption (Heaton 1991; Teachman 2002). Research suggests that the association can be partly explained by confounding factors, such as parental divorce and low educational attainment (Kiernan 1986). The literature provides various theoretical arguments, both psychological and sociological, that may account for the remaining effect of age at marriage. For example, researchers have argued that young people tend to be less mature and to make less forward-looking decisions, or that engaging in a short search on the marriage market may result in a relatively poor match (South 1995). Younger partners are also presumed to have more alternatives to their current relationship, and to be more prone to experience changes in their situations that affect the relationship. If early marriage is an indication of an insufficient search of the marriage market for a suitable spouse, those who married young will be more prone to divorce, as they are more likely to encounter a potential new partner. An American study found no support for this hypothesis (South 1995). 
It has been suggested that the inverse association between age at marriage and marital dissolution might not hold at higher ages. This could be because, as single women hear their biological clock ticking, they may settle for a less-than-optimal partner because they wish to have children. Some evidence to support this hypothesis has been provided by researchers in the United States (Lehrer 2008).

As the spouses age, they gain more personal maturity, which might make their unions more stable, and they might also encounter fewer potential partners for a new union, as their peers are less likely to be single. If it is found that current, running age also plays a role, it might be more appropriate to include in models of dissolution rates a variable of current age, rather than of age at entry into the union. However, because spouses' current ages and union duration are collinear, and because an efficient estimation of both effects requires richer and larger data sets than those that are usually available, this is seldom done. The idea that current age is a better predictor of divorce than age at marriage is nonetheless supported by one study from Finland (Lutz, Wils, and Nieminen 1991).

\section{Union type, union order, and same-sex unions}

When a couple decides to form a union, they can choose whether to move in together as cohabitants, or to get married before they start a joint household. After members of a given cohort have started to pair off and move in together, a continuous flow of cohabiting couples entering into marriage follows over the years. There is great variation among countries in these rates. In some countries, cohabitation is the modal pathway into marriage, while in others, this is no longer the case (Kiernan 2004; Kiernan 2001). Cohabitants have very low fertility in some countries, whereas, for example, in the Nordic countries and France, a large proportion of first births are to cohabiting mothers (Sobotka and Toulemon 2008). There is also some evidence of socioeconomic gradients in these choices. For example, in the United States, cohabiting parents have on average lower socioeconomic status than married parents (Carlson, McLanahan, and England 2004).

The rates of dissolution are generally higher for cohabitants than for married couples, even if the partners have common children (Andersson 2002; Andersson and Philipov 2002; Berrington 2001; Heuveline, Timberlake, and Furstenberg 2003; Jensen and Clausen 2003; Manning, Smock, and Majumdar 2004; Raley and Wildsmith 2004; $\mathrm{Wu}$ and Musick 2008). To the extent that lower levels of relationship satisfaction and commitment to the union keep cohabitants from marrying, the difference can be explained by self-selection of more stable unions from cohabitation into marriage. However, causal effects of getting or being married might also be involved, such as 
effects of going through the marriage ritual itself, more social support or pressure to stay together, and so on. We do not know very much about these potential causal effects of union type on the rate of dissolution. There is, however, a growing body of literature that reports causal effects of marital status on other outcomes, such as earnings and hours worked (Thomas and Sawhill 2002, Waite 1995); and these effects might in turn produce lower dissolution rates for married couples.

According to the search theory, couples who cohabit before getting married should have a lower subsequent risk of divorce than those who marry directly without having cohabited. During the premarital cohabitation period, it is argued, partners gain information about each other and the union, and only the unions with good prospects will be converted to marriages (Brüderl and Kalter 2001). A large number of empirical studies have, using a variety of data and methods, reached the exact opposite conclusion: the risk of divorce is higher after premarital cohabitation (Axinn and Thornton 1992; Berrington and Diamond 1999; Demaris and Macdonald 1993; Demaris and Rao 1992; Hall and Zhao 1995; Haskey 1992; Hoem and Hoem 1992; Teachman and Polonko 1990; Thomson and Colella 1992). The usual explanation for this finding is that the higher risk is chiefly due to self-selection: people who marry directly have a lower risk of dissolving any union due to unobserved, stable-over-time characteristics, such as a strong attachment to religion or conservative family values. Other mechanisms may also be involved. For example, prolonged experience as a cohabitant may weaken a person's concept of marriage as a preferred institutional framework for a sexual relationship (Thomson and Colella 1992). This represents a potential causal effect of cohabitation on marital dissolution rates that would increase the risk of divorce.

Statistically advanced studies of marital dissolution, in which the choice of union type and dissolution risk is modelled jointly, and which should therefore account for the selectivity into marriage to some extent, show quite different results (Brüderl, Diekmann and Engelhardt 1997; Lillard, Brien and Waite 1995; Svarer 2004). Generally, they find that there is serious selection into cohabitation, and that this is the main factor that accounts for the higher divorce rate among premarital cohabitors.

Further, a recent comparative study of 16 countries reported that the risk of divorce for former cohabitors was higher than that of people who married directly only in countries where premarital cohabitation is either a small minority or a large majority phenomenon (Liefbroer and Dourlejin 2006). An Australian study showed that the excess risk of divorce associated with premarital cohabitation has changed dramatically with successive marriage cohorts, and found a negative effect for more recent marriage cohorts (Hewitt and De Vaus 2009).

With increasing dissolution rates, more and more people enter second and subsequent unions. We have known for a long time that the risk of divorce is higher for 
second marriages than for first marriages (Martin and Bumpass 1989). Presumably, this is partly due to selection on unobserved characteristics. Studies that take such characteristics into account report that the selection out of first unions and into second unions is an important component of this higher risk (Poortman and Lyngstad 2007; Steele, Kallis; and Joshi 2006). Other suggested theoretical explanations for the higher divorce risk for higher-order unions include a lack of norms for post-dissolution family life, the role of step-children, experiences from the previous dissolution process, and the fact that second and subsequent unions are more likely to be cohabiting unions (Teachman 2008).

Same-sex unions have been given a legal framework similar to that of male-female marriages in several European countries since the early 1990s. Studies on these unions, conducted in Scandinavia and the Netherlands, have reported that the rate of divorce is higher for same-sex than for male-female marriages, and that female same-sex couples have the highest divorce rate (Andersson et al. 2006; Noack, Seierstad, and WeedonFekjær 2005). We also know that socioeconomic and demographic antecedents of divorce are fairly similar to those found for heterosexual marriages (Andersson et al. 2006; Kalmijn, Loewe, and Manting 2007).

\section{Children}

Having children is one of the main reasons why people form coresidential unions in the first place. Earlier contributions have usually found that having common children decreases the risk of divorce, at least when their number is limited to the usual low parities (Andersson 1997). The effect is at its strongest when the couple's children are very young, and wanes as they grow older (Waite and Lillard 1991).

Several theoretical links between childbearing and divorce have been suggested in the literature. Children are an example of so-called union-specific capital (Becker, Landes and Michael 1977). This means that the benefits gained from having children are bigger when the parents are living together than when they are not living together. Brines and Joyner (1999) have argued, on the basis of findings in experimental social psychology, that having children is a form of joint production that will increase the partners' commitment to the union. In addition, involuntary childlessness on the part of one or both partners may contribute to a higher dissolution risk among the childless. However, the lower divorce risk for couples with children is likely to be caused in part by selection, whereby spouses who have little trust in the continuity of their marriage are less likely to have children. Researchers from several countries have tried to address this problem by estimating the causal effects of having common children net of the selection component using different sophisticated statistical techniques (see, e.g., 
Lillard 1993). Judging from results reported from the United States, it seems that the couple's first child lowers the risk of divorce, whereas subsequent children have the opposite effect (Lillard and Waite 1993). Other studies using similar methods have concluded that second or later births reduce the risk of divorce in Italy and Spain, while in Denmark, a birth increases the risk of divorce (Coppola and Di Cesare 2008, Svarer and Verner 2006). Using multi-process methodology on British data, Steele et al. (2005) found that preschool children have a stabilizing effect on parents' married or cohabiting relationship, but also that the effect is weaker for older children.

In Sweden, the differences in divorce risk between childless women and mothers have diminished over the 1980s and 1990s (Andersson 1997). This could be a result of a change in the normative climate, in which norms prescribing that couples stay together for the sake of their children have weakened over time, but also of a change in the selection into marriage from cohabitation. As more couples have their first child in cohabitation, those who choose to marry while still childless could also be increasingly selected on, for example, being religious or having conservative family values. Steele et al. (2006) estimated the effect of parenthood on the outcomes of cohabiting relationships in the United Kingdom, and found that, for later cohorts, childbearing is increasingly compatible with cohabitation, but is less likely to lead to marriage.

A much-cited study from the United States reported that the divorce rate also depends on the sex composition of the couple's children: the risk of divorce was found to be lower for couples who had only male children than for couples who only had girls (Morgan, Lye and Condran 1988). The suggested explanation for this difference is the father involvement hypothesis (Katzev, Warner and Acock 1994), which states that fathers are more involved in the upbringing of their children if they have at least one son than they would be otherwise. The original finding, which alludes to the existence of gender preferences among parents in industrial societies (Andersson et al. 2006), was hailed as the most interesting finding in divorce research in the 1980s (White 1990). European researchers have not, however, been able to replicate it consistently. A study with superior data from Swedish registers found little systematic support for a lower divorce risk for couples with only sons, and suggested that the finding of Morgan, Lye, and Condran (1988) could be attributed to random variation in the data (Andersson and Woldemicael 2001). A comparative study of 16 European countries, Canada, and the United States repudiated the general hypothesis that sons contribute more to marital stability than daughters (Diekmann and Schmidheiny 2004).

Some other issues have also been clarified: couples with twins do not seem to have higher divorce rates than couples with two singletons (Walke 2002). Having a first birth within wedlock has been reported to decrease the risk of divorce in Norway and Sweden (Kravdal 1988; Liu 2002). This effect is most likely due to selection of 
particularly stable couples into marriage before the first birth, as in these countries, the majority of first births are now to cohabiting mothers.

Studies from the Netherlands (Kalmijn and Poortman 2006) and Australia (Hewitt 2009) included data on whether the wife, the husband, or both took the initiative in the divorce process: the Dutch study concluded that children aged 0-6 had a stronger negative effect on the risk of husband-initiated divorce than on wife-initiated divorce or on divorce initiated by both partners. However, the Australian study found weak evidence that wives are less likely than husbands to initiate when they have infants, and that husbands are less likely than wives to initiate when children are school-age or older.

\section{Educational attainment}

Both in Europe and in America, the impact of the socioeconomic positions of the spouses on the risk of divorce has received considerable attention. There are several themes that emerge from this part of the literature. One of them deals with the impact of the educational attainment of the two spouses and the potential interaction effect between the two, which essentially represents the potential effect of educational homogamy. When considering the effect of education on union dissolution risk, it is important to keep in mind that various selection processes, as well as possible causal influences, together produce the educational gradient. In addition, educational attainment is correlated with earnings potential and labor market activity. Thus, most studies of education effects try, in some way or another, to separate the effects of education per se from the effects of spouses' incomes and their labor market activity status.

Almost all studies in which a definitive conclusion was reached reported a negative effect of the husband's level of formal education on the risk of divorce. Over the past few decades, Scandinavian studies - mostly based on large- $N$ register data, which allow for the precise estimation of parameters - have consistently found negative effects of both spouses' educational attainments on the risk of divorce (Hoem 1997; Jalovaara 2001). In the United States, as well, a negative effect of the wife's level of education has been shown (Martin 2006; Ono 1998). The evidence from some European countries is more mixed. A study from the Netherlands reported a positive effect of the wife's higher education on the risk of divorce (Poortman and Kalmijn 2002), as did one Italian study (de Rose 1992). These differences may be assigned a normative explanation, such as the so-called Goode hypothesis. This hypothesis states that, in a society in which divorce is relatively infrequent and represents a notable breach of social norms, it might take more resources to dissolve a marriage (Goode 
1962). The prediction is thus that the correlation between socioeconomic status and divorce risk shifts from being positive to negative over time if divorce rates increase. Several studies make reference to this hypothesis when studying the effect of educational attainment on divorce risk (Blossfeld et al. 1995; de Graaf and Kalmijn 2006; Hoem 1997; Härkonen and Dronkers 2006). Using multi-country data with differing divorce contexts, Blossfeld et al. (1995) found that education affected divorce rates differently in Sweden, West Germany, and Italy; and suggested that these countries are at different stages in a transition from a social context marked by low divorce rates, to one with high divorce rates. In Italy, the divorce rate has increased substantially over the last few years, and the Goode hypothesis leads us to expect that the educational gradient is turning negative. However, the most recent Italian study found higher divorce risks for women with university-level degrees (Vignoli and Ferro 2009). Recently, several European teams have found some support for the Goode hypothesis by estimating time-varying effects of educational attainment on divorce (de Graaf and Kalmijn 2006; Härkonen and Dronkers 2006). A similar study, but using American data, found no evidence for a changing effect of education across marriage cohorts (Teachman 2002).

Overall, homogamy, or similarity in partners' characteristics, is the norm in partner selection, and the usual hypothesis is that homogamy strengthens unions (Kalmijn 1998). Studies from Nordic countries have not found the risk of divorce to be especially high among educationally heterogamous couples (Finnäs 1997; Jalovaara 2003; Lyngstad 2004; Svarer and Verner 2006). In contrast, an earlier study from the United States reported a divorce-promoting effect of educational heterogamy (Tzeng 1992). There is also some evidence suggesting that changes in educational attainment during marriage increase the risk of divorce (Lyngstad 2004; Tzeng and Mare 1995). Generally, the effects of education are at their strongest early in the marriage (Jalovaara 2002).

\section{Employment and income}

How do spouses' employment and income affect marital stability? The point of departure for the great majority of studies focusing on this question is the Beckerian specialization model (Becker, Landes and Michael 1977). This model states that the gain from marriage is highest when the one of the spouses specializes in paid market work, and the other in nonmarket work (housework and care). Given the persistence of historical gender roles and a gender wage gap, this means that we should expect to see a lower divorce risk when the husband specializes in market work, and the wife in domestic production and reproduction (or works part-time at most). The divorce- 
promoting effect of the wife's greater resources is referred to as the 'independence effect.' The wife's resources also add to the total resources of the family, which should increase marital stability (the 'income effect'), but the independence effect is thought to outweigh any advantages (Ross and Sawhill 1975). To most readers, the specialization model seems anachronistic in contemporary Western societies. It has been widely criticized (see, e.g., Sayer and Bianchi 2000), and an alternative model has been proposed, in which the utility is highest when both partners contribute economically to the household (Oppenheimer 1997).

American studies offer mixed evidence of an independence effect of women's earnings. A non-linear relationship between the wife's income and union stability is not uncommonly encountered (Heckert, Nowak, and Snyder 1998; Ono 1998; Rogers 2004), and the results seem to depend on whether the focus is on the wife's absolute income, or on her relative contribution to the total family income (Rogers 2004). In Europe, most contributions have tended to support the independence effect (see, e.g., Bukodi and Robert 2003; Chan and Halpin 2002; Henz and Jonsson 2003; Tjøtta and Vaage 2003), but there are also studies that have found negative effects on dissolution rates of the wife's income (Svarer and Verner 2006) The independence hypothesis also holds when other correlates of the female's socioeconomic status or economic potential, such as occupational class and educational attainment, are controlled for effectively (Jalovaara 2001). A study using Finnish register data from the early 1990s estimated relative divorce risks for combinations of the spouses' levels of income. The husband's high income decreased the risk, and the wife's high income increased it, regardless of the level of the other spouse's income, but the divorce-promoting effect of the wife's high income was especially strong when the husband's income was low (Jalovaara 2003).

Many scholars have argued that the wife's economic resources do not undermine the quality or gains of marriage, but that the presence of these resources may lower a barrier for her to leave a troubled marriage. There is empirical support for this view from studies that include measures of marital quality or happiness (Sayer and Bianchi 2000; Schoen et al. 2002). Further, a recent Dutch study found that the divorcepromoting effect of the wife being employed was stronger when she reported having initiated the dissolution process (Kalmijn and Poortman 2006). A problem that plagues all studies of the effects of the wife's income on dissolution risk is that the theoretical predictions are derived for the wife's economic potential, while analyses are in most cases based on her actual earnings. In most empirical studies, only crude measurements of earnings are available, while measurements of hourly wages are lacking. Another issue is that women who are dissatisfied with their current relationship may increase their labor supply because they anticipate a dissolution and are preparing to become single; thus, the higher divorce risk of employed wives and of wives with high incomes 
could be due to anticipation of a dissolution. A recent test of this hypothesis from the Netherlands did not, however, provide any evidence to support it (Poortman 2005).

An American study examined time dependencies in the effect of wives' employment on divorce risk. A divorce-promoting effect of wife's employment was found, but only towards the end of the period, or after the mid-1980s (South 2001b). The gender-specific effects of income, labor force participation, and division of labor are likely to be closely related to gender ideology. For example, it is likely that wives who perform domestic work full-time in a context in which most women participate in the labor force are selected for having more traditional family values than other women, and this may be an important reason for the increasingly positive effect of wives' employment on divorce.

Brines and Joyner (1999) found that cohabiting couples in the United States in which the partners' employment and earnings were similar had a sharply reduced risk of disruption, while married couples had the lowest risk if they adopted a specialized division of labor. A Dutch study using administrative register data on both married and cohabiting couples found negative effects of total household income on separation, and positive effects of the woman's relative income (Kalmijn, Loeve and Manting 2007). However, in this case as well, the effects depended on the type of union. The findings suggested that equality led to a lower separation risk for cohabitants, while the traditional arrangement, in which the man is the main provider, led to a lower separation risk for married couples. The woman being the main provider increased the risk for both types of unions.

Work-life balance is closely related to the effects of income and labor force participation on divorce. The direction of causality is, however, again difficult to establish. An American study reported that working shift or rotation schedules increased the risk of divorce (Presser 2000). About 15\% of the higher divorce risk for Dutch husbands working less than full-time could be attributed to the couple experiencing more financial pressures (Poortman 2005). In Norway, the introduction of a cash-for-care benefit, which transfers money to parents who do not use public subsidized childcare (and thereby increases the likelihood that one of the parents will stay at home), had the effect of reducing marital dissolution (Hardoy and Schone 2008).

What effects do economic shocks, like sudden unemployment or other sharp changes in earnings, have on marriage? There is some evidence from both Europe and the United States supporting the hypothesis that economic instability or hardship in the household increases the likelihood of marriage dissolution (Conger et al. 1990; Lewin 2005; Poortman 2005). For example, a husband's unemployment has been shown to increase dissolution rates in Norway, Finland, Germany, and the United States (Hansen 2005; Jalovaara 2001; Kraft 2001; Lewin 2005; Sander 1992). Fewer studies have examined the impact of a wife's unemployment, but results from Scandinavia have 
shown a divorce-promoting effect (Hansen 2005; Jalovaara 2001; 2003). In line with economic search theory, sudden changes in the partner's economic contribution have been found to increase the risk of divorce (Böheim and Ermisch 2001; Weiss and Willis 1997).

\section{Gender perspectives, values, and religiosity}

Recently, more attention has been given to the partners' own views on gender roles, and to how socio-political differences across societies may modify the effects of intrahousehold arrangements on marital stability.

A study that used Dutch data found that the risk of divorce is lower for couples who hold on to the traditional, gender-specialized division of labour, but only if the wife's views are traditional. The effect of the division of labor is thus contingent on gender ideology and the concordance of the couple's cultural and economic dispositions; the traditional arrangement would not affect the risk of divorce, as such (Kalmijn, de Graaf and Poortmann 2004). In the United States, men with egalitarian gender role attitudes have been found to divorce less often than other men (Kaufman 2000), while employed women with a nontraditional (egalitarian) gender role ideology have been found to divorce more often (Greenstein 1995). Hohmann-Marriot (2006) found that that couples, and in particular cohabiting couples, who do not share beliefs about the division of household labour are more likely to end their union. Domestic violence is, of course, a cause of marital dissolution (Kingston-Riechers 2001).

A study comparing divorce behavior in the United States and in Germany showed that, in the German context, where the male breadwinner family has been more strongly promoted by the state, a wife's greater contribution to household earnings or a husband's greater involvement in housework increased the risk of divorce; while in the United States, the most stable relationships were found among couples with the highest degree of gender equity (Cooke 2006).

Another Dutch study reported that the magnitude of the effect of several factors on the risk of divorce depended on whether the wife, the husband, or both had initiated the divorce (Kalmijn and Poortman 2006). For example, the divorce-promoting effect of the wife being employed was found to be stronger when she reported initiating the dissolution process. Furthermore, having children was shown to decrease the likelihood of husband-initiated divorce more than wife- or couple-initiated divorce. A likely explanation is that fathers may have more to lose than mothers following a divorce in terms of influence over their children and opportunities to spend time with them.

Religious views on marriage and divorce may deter individuals from dissolving their unions directly, but there may also be more indirect pathways of influence 
involving social and ideological factors. Indeed, the risk of divorce is lower for persons who are strongly religious (Lehrer 2004). Disaffiliation has been reported to increase the risk of divorce (Trovato 1993), whereas greater service attendance decreases the risk (Bracher et al. 1993; Brown, Orbuch and Bauermeister 2008). Religious homogamy seems to reduce divorce risk somewhat, even if one of the spouses is a convert to the partner's religion. There is likely to be some conflict potential if the two partners are committed to distinct religions with different teachings on central issues, or if members of the two denominations tend to hold social values that are incompatible (Kalmijn, de Graaf and Janssen 2005; Lehrer 2004; Lehrer and Chiswick 1993; Trovato 1993).

\section{Migration and minority status}

Moving to a new community is a stressful life event, and can sever ties to the social network the partners were embedded in while living in the previous location. In addition, one of the partners may benefit more from the move than the other. Several studies have found that mobility increases the risk of dissolution (Boyle et al. 2008; Frank and Wildsmith 2005; Muszynska and Kulu 2007).

Quite often, models of union dissolution rates include variables that capture effects of belonging to some minority-status group, which may be defined, for example, by immigration history or ethnic or linguistic boundaries. Of particular theoretical interest are couples who, by forming a union, have crossed the majority-minority boundary. Crossing such boundaries may impede the degree of mutual understanding and shared world-views between partners, and may also affect the level of social support the couple receives (Kalmijn 1998).

In the United States, race and ethnic origin are of major interest to demographers, as there are marked differences across racial lines in divorce rates and other demographic outcomes, with rates of dissolution being higher for African-Americans than for other groups (Cherlin 1998; Kposowa 1998; Phillips and Sweeney 2005; 2006; Sweeney and Phillips 2004). Interracial couples were reported to have higher risks of divorce than endogamous marriages, but once the ages and education levels of the partners were controlled for, the divorce risk among these couples was found to be similar to that of the more divorce-prone racial group (Zhang and Hook 2009).

This is a topic which, so far, has not attracted much attention from European researchers, but is bound to figure more prominently in the future, given the large and growing European immigrant populations. Recently, a significantly higher divorce risk for marriages between Dutch nationals and foreigners has been documented (Kalmijn, de Graaf and Janssen 2005). 
Studies of the Swedish-speaking population in Finland, a minority language group, have found that couples that consist of two Swedish speakers had a significantly lower divorce rate than couples who are Finnish speakers. The rate for mixed couples was shown to be even slightly higher than for unilingual Finnish-speaking couples (Finnäs 1997).

\section{Intergenerational transmission processes}

A major finding in research on union dissolution is that divorce is more likely when the parents of either or both of the spouses have divorced. Several studies from Europe, as well as from North America, have documented and tried to explain this so-called intergenerational transmission of divorce (Amato 1996; Amato and DeBoer 2001; Diekmann and Schmidheiny 2006; Lyngstad and Engelhardt 2009; Traag, Dronkers, and Vallet 2000). Various explanations have been given for the intergenerational transmission of divorce. One that received considerable attention in early studies is father absence: i.e., the idea that children who experience parental divorce, and who therefore have little or no contact with their fathers, will not learn appropriate father and husband behaviour from role models; and that this absence will in turn generate problems in the children's own marriages. An example of a test of the father absence explanation involved natural experiment data from Germany. After individuals who lost their fathers during World War II were compared both with individuals whose parents divorced and individuals from intact families, the father absence hypothesis was not confirmed (Diekmann and Engelhardt 1999). Another explanation with many adherents is that poorer socioeconomic circumstances increase the divorce risk among both parents and their offspring. Neither this nor the father absence explanation fully account for the intergenerational transmission of divorce (Wolfinger 2005). One study using data on twins concluded that the intergenerational transmission of divorce is partly due to selection on genetic factors, but the results also supported the presence of causal transmission effects (D'Onofrio et al. 2007).

Much effort has gone into identifying the causal links between parents' divorces and those of their offspring. According to Wolfinger (2005), the explanation for intergenerational transmission of divorce that has so far received the most support in the research is that a couple's divorce leads to their children having lower levels of marital commitment (usually defined as the tendency to remain in a marriage despite marital troubles or appealing alternatives) which in turn translates into higher divorce risks for the children (Amato 1996; Amato and DeBoer 2001). Other less prominent explanations include the observations that children of divorce may have worse 
relationship skills, and may have less exposure to same-sex role models (Amato and DeBoer 2001).

Variables such as the type of and age at entry into a first union partly mediate this relationship. For example, children with divorced parents more often choose to cohabit (Engelhardt, Trappe, and Dronkers 2002; Kiernan and Cherlin 1999). The tendency of children of divorce to choose each other as marital partners can exacerbate the risk of divorce (Wolfinger 2003). A study by Gähler, Hong, and Bernhardt (2009) reported that the transmission effect for both cohabitation and marriage dissolution in Sweden disappeared once commitment to the union, attitudes towards divorce, interpersonal behavior indicators, as well as life course and socioeconomic conditions, were controlled for.

There is currently a discussion underway about whether there is a time trend in the strength of the intergenerational transmission of divorce. This question is based on the idea that the consequences of divorce may weaken when divorce becomes a more common phenomenon. Conflicting results have so far been reported, with Wolfinger (1999) finding a decline in transmission strength, and Teachman (2002) reporting no such decline. Recently, $\mathrm{Li}$ and $\mathrm{Wu}$ (2008) have argued that the decline observed by Wolfinger (1999) was due to limitations of the data and methods used.

Another factor related to processes of intergenerational transmission that has been linked with divorce is the parents' higher socioeconomic status. Measured by either the parents' occupations or levels of education, this factor has been reported to increase the risk of marital dissolution risk in Scandinavia, net of spouses' own education levels (Hoem and Hoem 1992; Lyngstad 2006b), in the Netherlands (Klijzing 1992), and in the United States (Bumpass, Martin, and Sweet 1991). It is not clear what processes are behind this effect, but suggestions include the possibility that the offspring of the highly educated have more liberal views on divorce.

\section{Biological and health-related factors}

Although most of the research on health and divorce is concerned with the possible health-related consequences of divorce for either the spouses themselves, or for their children, some studies have focused on the effect of health on the risk of divorce. High levels of psychological well-being are found to decrease divorce risk, particularly in the short run (Mastekaasa 1994). Excessive use of alcohol and the use of illegal drugs have been found to increase the risk of divorce (Collins, Ellickson, and Klein 2007; Kaestner 1997, Ostermann, Sloan, and Taylor 2005; Power and Estaugh 1990). Having a physically frail or disabled child increases the risk of marital dissolution (Corman and Kaestner 1992; Mauldon 1992; Najman et al. 1993; Reichman, Corman, and Noonan 
2004). Being diagnosed with cancer has not been found to affect the risk of divorce, with the exception of cervical and testicular cancers, which were shown to increase the risk (Syse and Kravdal 2007). Differences in health status between spouses have been found to increase divorce risk even for couples who otherwise find their relationship satisfying (Wilson and Waddoups 2002). Although speculation exists in the literature about the effects of the death of a child on marriage dissolution (Najman et al. 1993), reviews have concluded that there is no available study that offers a reliable evaluation of the divorce risk among bereaved parents (Oliver 1999; Schwab 1998). Cancer in a child has no marked influence on divorce (Syse, Loge and Lyngstad 2010).

A study using data on twins found that there is a genetic influence on divorce risk (McGue and Lykken 1992). One study of American men concluded that high levels of testosterone made men more likely to leave their spouse (Booth and Dabbs 1993), but this relies on an assumption that levels of testosterone are stable over time, which does not appear to be the case (Mazur and Michalek 1998).

\section{Contextual factors}

It has been suggested that various societal characteristics, in addition to couple characteristics, influence dissolution risks. The most common approach to investigating these characteristics is including an indicator of place of residence in models of dissolution rates. A consistent finding from such studies is that the divorce rate is higher for urbanites than for couples residing in rural areas, when other couple-level predictors are controlled for (Bracher et al. 1993; Lyngstad 2006a). The theoretical explanations for this difference include lower search costs for finding a new partner in urban areas, and higher levels of social integration in rural areas.

The availability of potential mates in the local marriage market has been argued to affect the likelihood of union dissolution. This theoretical argument, which is sometimes referred to as "the macro-structural opportunity theory of marital dissolution" (South, Trent, and Shen 2001), maintains that a greater likelihood of encountering a preferable new partner increases the propensity to dissolve an ongoing union (Udry 1981, 1983). However, it is difficult to define and measure these markets of partners. Administrative or geographical units are generally used to define the arena of partner search, but both small workplaces, and U.S. labor market areas comprising millions of persons, have been used (see, e.g., South and Lloyd 1995, Svarer 2007). A contribution that is frequently cited in this field is a study that found that divorce risk increases when the local sex ratio of available mates is unbalanced (South and Lloyd 1995). Despite relying on several assumptions about the definition of the "partner market," this finding has been replicated with other U.S. data, in which the skewness of 
occupational sex distributions was found to increase the risk of divorce (McKinnish 2004, South, Trent, and Shen 2001). In line with this finding, a recent Danish study reported that the risk of divorce is higher for couples among whom the wife worked in a male-dominated occupation (Svarer 2007).

It has been hypothesized that a high concentration of economically disadvantaged persons in the local community generates a milieu conducive to family instability (South 2001a). The support for this hypothesis is rather scant. A study using data from the United States reported that economic deprivation in the neighborhood did not affect the risk of divorce once couple-level resources were controlled for (South 2001a), and a register-based study found no effect on divorce rates of average income and the male unemployment rate in Norwegian municipalities, net of unobserved factors at the municipality level, as well as couple-level predictors (Lyngstad 2006a). However, a study from the Netherlands showed that the risk of union dissolution is lower when consumer confidence is high, net of individual-level predictors of dissolution (Fischer and Liefbroer 2006).

An analysis of Russian data that distinguished between the socialist regime and the post-socialist transitory system that followed found that there were no important differences in employment-related factors in either period, with the exception that, in the post-socialist period, employees of private companies divorced more frequently than others (Muszynska 2008).

\section{National divorce legislation}

Changes in divorce legislation are often preceded by de facto changes in norms and attitudes, but may also reinforce attudinal change (Phillips 1991). Support for the former claim comes from Kneip and Bauer (2009), who, after examining the impact of unilateral divorce on the divorce rate in a number of Western European countries, found that increased legal rights to unilateral divorce had no long-run effects. In the United States, there was a major expansion of no-fault divorce laws in the 1970s, but this legal change does not seem to have had any lasting effect on the rate of divorce (Wolfers 2006). It might have short-term effects, as couples may adjust the timing of divorce in anticipation of the legal changes, or finally obtain a legal divorce after having lived separately for a longer period of time. A study of historical divorce data from the Netherlands also supports this view (van Poppel and De Beer 1993).

Another area of the law that might have an impact on union dissolution rates concerns the rules and laws pertaining to child support after a breakup, and the government's enforcement of such rules. In the United States and the United Kingdom, studies have shown that stronger enforcement of child support decreases the likelihood 
of a breakup (Nixon 1997; Walker and Zhu 2006), and that, in the United States, this effect is at its strongest in situations where the mother is likely to be a welfare recipient after the split (Nixon 1997).

\section{Conclusions}

Our knowledge of the antecendents of divorce has increased over the last two decades. Higher dissolution rates and other changes in the family system call for a broader perspective that links the two partners' decision-making to their accumulated experiences from childhood, previous partnerships and childbearing, as well as education and employment careers.

From this review, it is evident that researchers have broadened their approach to union dissolution. Despite the fact that most of the studies reviewed were studies of divorce, there is a much stronger focus on cohabitation in the literature. The processes of choice of union type, both at the outset of the coresidential union and the stream of cohabitating couples into marriage (Steele, Kallis, and Joshi 2006), have received attention. Other outcomes of the mate selection process, such as what patterns of homogamy and endogamy mean for union dissolution, also figure prominently in the current literature.

Differences in institutions and culture across societies provide both challenges and opportunities for researchers, as a meta-analysis has shown that the variation between contexts in the effects of typical antecedents of divorce is large (Wagner and Weiss 2006). A trend over the past several decades, facilitated by survey programs such as the Family and Fertility Survey, has been to use comparative data to study such variations. The problems addressed include intergenerational transmission of dissolution risk (Härkönen and Dronkers 2008), changes in the effect of the wife's education (Härkonen and Dronkers 2006), the effect of child gender on divorce risk (Diekmann and Schmidheiny 2004), and the ways in which the prevalence of premarital cohabitation affect subsequent divorce risk (Liefbroer and Dourlejin 2006).

To further theoretical development in this field, researchers should make a more systematic attempt to identify causal mechanisms leading to gradients in divorce rates, and to disentangle these gradients from selection effects. In the wider social science literature, there is, increasingly, a focus on more complex methods for identifying causal effects (see, e.g., Winship and Morgan 1999). A typical statistical approach in studies of union dissolution is hazard regression models, whereby sets of independent variables, such as indicators of the presence of children in a union, are regressed on the rate of union dissolution. Conclusions from simple models with such variables give us important insights into demographic development, but, due to selection effects, less 
insight, for instance, into the role of children as a barrier to divorce. Using simultaneous hazard models has been suggested as a remedy to this problem (Lillard 1993; Lillard and Waite 1993; Steele et al. 2005). An increasing complexity of statistical methods and a stronger focus on identification of causal effects are likely to become more common in the decades to come, as data availability and statistical expertise increase.

\section{Acknowledgements}

The authors are grateful to Gunn E. Birkelund and Øystein Kravdal for their comments on a very early draft, and to the two Demographic Research reviewers and the Associate Editor for their comments. The Research Council of Norway provided funding for the project through their grant number 159666/730. 


\section{References}

Amato, P.R. (1996). Explaining the Intergenerational Transmission of Divorce. Journal of Marriage and the Family 58(3): 628-640. doi:10.2307/353723.

Amato, P.R. (2000). The Consequences of Divorce for Adults and Children. Journal of Marriage and the Family 62(4): 1269-1287. doi:10.1111/j.17413737.2000.01269.x.

Amato, P.R. and DeBoer, D.D. (2001). The Transmission of Marital Instability Across Generations: Relationships Skills or Committment to Marriage. Journal of Marriage and the Family 63(4): 1038-1051. doi:10.1111/j.17413737.2001.01038.x.

Andersson, G. (1997). The Impact of Children on Divorce Risks of Swedish Women. European Journal of Population 13(2): 109-145. doi:10.1023/A:1005803001129.

Andersson, G. (2002). Children's experience of family disruption and family formation: Evidence from 16 FFS countries. Demographic Research 7(7): 343-364. doi:10.4054/DemRes.2002.7.7.

Andersson, G., Hank, K., Rønsen, M., and Vikat, A. (2006). Gendering Family Composition: Sex Preferences for Children and Childbearing Behavior in the Nordic Countries. Demography 43(2): 255-267. doi:10.1353/dem.2006.0010.

Andersson, G., Noack, T., Seierstad, A., and Weedon-Fekjær, H. (2006). The Demographics of "Same-Sex" Marriages in Norway and Sweden. Demography 43(1): 79-98. doi:10.1353/dem.2006.0001.

Andersson, G. and Philipov, D. (2002). Life-table representations of family dynamics in Sweden, Hungary, and other 14 FFS countries: a project of descriptions of demographic behavior. Demographic Research 7(4): 67-270. doi:10.4054/DemRes.2002.7.4.

Andersson, G. and Woldemicael, G. (2001). Sex composition of children as a determinant of marriage disruption and marriage formation: evidence from Swedish register data. Journal of Population Research 18(2): 143-153. doi:10.1007/BF03031886.

Axinn, W.G. and Thornton, A. (1992). The Relationship between Cohabitation and Divorce - Selectivity or Causal Influence. Demography 29(3): 357-374. doi: $10.2307 / 2061823$. 
Becker, G.S., Landes, E.M., and Michael, R.T. (1977). An Economic Analysis of Marital Instability. Journal of Political Economy 85(6): 1141-1188. doi:10.1086/260631.

Berrington, A. (2001). Entry into parenthood and the outcome of cohabiting partnerships in Britain. Journal of Marriage and the Family 63(1): 80-96. doi:10.1111/j.1741-3737.2001.00080.x.

Berrington, A. and Diamond, I. (1999). Marital dissolution among the 1958 British birth cohort: The role of cohabitation. Population Studies 53(1): 19-38. doi:10.1080/00324720308066.

Blossfeld, H.-P., de Rose, A., Hoem, J.M., and Rohwer, G. (1995). Education, Modernization, and the Risk of Marriage Disruption in Sweden, West Germany, and Italy. In: Mason, K.O. and Jensen, A.-M. (eds.). Education, Modernization, and the Risk of Marriage Disruption in Sweden, West Germany, and Italy. Oxford: Clarendon Press

Böheim, R. and Ermisch, J. (2001). Partnership dissolution in the UK - the role of economic circumstances. Oxford Bulleting of Economics and Statistics 63(2): 197-208. doi:10.1111/1468-0084.00216.

Booth, A. and Dabbs, J.M. (1993). Testosterone and Mens Marriages. Social Forces 72(2): 463-477. doi:10.2307/2579857.

Boyle, P.J., Kulu, H., Cooke, T., Gayle, V., and Mulder, C.H. (2008). Moving and union dissolution. Demography 45(1): 209-222. doi:10.1353/dem.2008.0000.

Bracher, M., Santow, G., Morgan, S.P., and Trussel, J. (1993). Marriage Dissolution in Australia: Models and Explanations. Population Studies 47(3): 403-425. doi:10.1080/0032472031000147216.

Bradbury, T.N., Fincham, F.D., and Beach, S.R.H. (2000). Research on the nature and determinants of marital satisfaction: A decade in review. Journal of Marriage and the Family 62(4): 964-980. doi:10.1111/j.1741-3737.2000.00964.x.

Brines, J. and Joyner, K. (1999). The ties that bind: Principles of cohesion in cohabitation and marriage. American Sociological Review 64(3): 333-355. doi: $10.2307 / 2657490$.

Brown, E., Orbuch, T.L., and Bauermeister, J.A. (2008). Religiosity and marital stability among Black American and White American couples. Family Relations 57(2): 186-197. doi:10.1111/j.1741-3729.2008.00493.x. 
Brüderl, J., Diekmann, A., and Engelhardt. H. (1997). Erhöht eine Probeehe das Scheidungsrisiko? Eine empirische Untersuchung mit dem Familiensurvey. Kölner Zeitschrift für Soziologie und Sozialpsychologie 49(2): 205-222.

Brüderl, J. and Kalter, F. (2001). The Dissolution of Marriages: The Role of Information and Marital-Specific Capital. Journal of Mathematical Sociology 25: 403-421.

Bukodi, E. and Robert, P. (2003). Union Disruption in Hungary. International Journal of Sociology 33(1): 64-94.

Bumpass, L.L., Martin, T.C., and Sweet, J.A. (1991). The Impact of Family Background and Early Marital Factors on Marital Disruption. Journal of Family Issues 12(1): 22-42. doi:10.1177/019251391012001003.

Carlson, M., McLanahan, S., and England, P. (2004). Union Formation in Fragile Families. Demography 41(2): 237-261. doi:10.1353/dem.2004.0012.

Chan, T.W. and Halpin, B. (2002). Union Dissolution in the United Kingdom. International Journal of Sociology 32(4): 76-93.

Cherlin, A.J. (1998). Marriage and marital dissolution among Black Americans. Journal of Comparative Family Studies 29(1): 147.

Collins, R.L., Ellickson, P.L., and Klein, D.J. (2007). The role of substance use in young adult divorce. Addiction 102(5): 786-794. doi:10.1111/j.13600443.2007.01803.x.

Conger, R.D., Elder, G.H., Lorenz, F.O., Conger, K.J., Simons, R.L., Whitbeck, L.B., Huck, S., and Melby, J.N. (1990). Linking Economic Hardship to Marital Quality and Instability. Journal of Marriage and the Family 52(3): 643-656. doi:10.2307/352931.

Cooke, L.P. (2006). "Doing" Gender in Context: Household Bargaining and Risk of Divorce in Germany and the United States. American Journal of Sociology 112(2): 442-472. doi:10.1086/506417.

Coppola, L. and Di Cesare, M. (2008). How fertility and union stability interact in shaping new family patterns in Italy and Spain. Demographic Research 18(4): 117-144. doi:10.4054/DemRes.2008.18.4.

Corman, H. and Kaestner, R. (1992). The Effects of Child Health on Marital Status and Family Structure. Demography 29(3): 389-408. doi:10.2307/2061825. 
D'Onofrio, B.M., Turkheimer, E., Emery, R.E., Harden, K.P., Slutske, W.S., Heath, A.C., Madden, P.A.F. and Martin, N.G. (2007). A Genetically Informed Study of the Intergenerational Transmission of Marital Instability. Journal of Marriage and Family 69(3): 793-809. doi:10.1111/j.1741-3737.2007.00406.x.

de Graaf, P.M. and Kalmijn, M. (2006). Change and Stability in the Social Determinants of Divorce: A Comparison of Marriage Cohorts in the Netherlands. European Sociological Review 22(5): 561-572. doi:10.1093/esr/jc1010.

de Rose, A. (1992). Socio-Economic Factors and and Family Size and Determinants of Marital Dissolution in Italy. European Sociological Review 8(1): 71-91.

DeMaris, A. and Macdonald, W. (1993). Premarital Cohabitation and Marital Instability - a Test of the Unconventionality Hypothesis. Journal of Marriage and the Family 55(2): 399-407. doi:10.2307/352810.

DeMaris, A. and Rao, K.V. (1992). Premarital Cohabitation and Subsequent Marital Stability in the United-States - a Reassessment. Journal of Marriage and the Family 54(1): 178-190. doi:10.2307/353285.

Diekmann, A. and Engelhardt, H. (1999). The Social Inheritance of Divorce: Effects of parents' Family Type in Postwar Germany. American Sociological Review 64:783-793. doi:10.2307/2657402.

Diekmann, A. and Schmidheiny, K. (2004). Do parents of girls have a higher risk of divorce? An Eighteen-Country Study. Journal of Marriage and the Family 66(3): 651-660. doi:10.1111/j.0022-2445.2004.00044.x.

Diekmann, A. and Schmidheiny, K. (2006). The Intergenerational Transmission of Divorce. Results From a Sixteen-Country Study with the Fertility and Family Survey. [unpublished manuscript]. Paper presented at the Population Association of America Annual Meeting 2006 in Los Angeles, California.

Engelhardt, H., Trappe, H., and Dronkers, J. (2002). Differences in family policy and the intergenerational transmission of divorce: A comparison between the former East and West Germany. Demographic Research 6(11): 295-323. doi:10.4054/DemRes.2002.6.11.

Finnäs, F. (1997). Social integration, heterogeneity, and divorce: The case of the Swedish-speaking population in Finland. Acta Sociologica 40(3): 263-277. doi:10.1177/000169939704000303. 
Fischer, T. and Liefbroer, A.C. (2006). For Richer, For Poorer: The Impact of Macroeconomic Conditions on Union Dissolution Rates in the Netherlands 1972-1996. European Sociological Review 22(5): 519-532. doi:10.1093/esr/jcl013.

Frank, R. and Wildsmith, E. (2005). The grass widows of Mexico: Migration and union dissolution in a binational context. Social Forces 83(3): 919-947. doi:10.1353/sof.2005.0031.

Gahler, M., Hong, Y., and Bernhardt, E. (2009). Parental Divorce and Union Disruption Among Young Adults in Sweden. Journal of Family Issues 30(5): 688-713. doi:10.1177/0192513X08331028.

Goode, W.J. (1962). Marital Satisfaction and Instability: A Cross-Cultural Class Analysis of Divorce Rates. In: Bendix, R. and Lipset, S.M. (eds.). Marital Satisfaction and Instability: A Cross-Cultural Class Analysis of Divorce Rates. New York: The Free Press.

Gottman, J.M. and Notarius, C.I. (2000). Decade Review: Observing Marital Interaction. Journal of Marriage and the Family 62(4): 927-947. doi:10.1111/j.1741-3737.2000.00927.x.

Greenstein, T.N. (1995). Gender Ideology, Marital Disruption, and the Employment of Married-Women. Journal of Marriage and the Family 57(1): 31-42. doi:10.2307/353814.

Härkonen, J. and Dronkers, J. (2006). Stability and Change in the Educational Gradient of Divorce. A Comparison of Seventeen Countries. European Sociological Review 22(5): 501-517.

Härkönen, J. and Dronkers, J. (2008). The intergenerational transmission of divorce in cross-national perspective: Results from the Fertility and Family Surveys. Population Studies 62(3): 273-288.

Hall, D.R. and Zhao, J.Z. (1995). Cohabitation and Divorce in Canada - Testing the Selectivity Hypothesis. Journal of Marriage and the Family 57(2): 421-427. doi:10.2307/353695.

Hansen, H.-T. (2005). Unemployment and Marital Dissolution. European Sociological Review 21(2): 135-148. doi:10.1093/esr/jci009.

Hardoy, I. and Schone, P. (2008). Subsidizing "Stayers"? Effects of a Norwegian child care reform on marital stability. Journal of Marriage and the Family 70(3): 571584. doi:10.1111/j.1741-3737.2008.00506.x. 
Haskey, J.C. (1992). Pre-marital cohabitation and the probability of subsequent divorce: analyses using new data from the General Household Survey. Population Trends 68: 10-19.

Heaton, T.B. (1991). Time-Related Determinants of Marital Dissolution. Journal of Marriage and the Family 53(2): 285-295. doi:10.2307/352899.

Heckert, D.A., Nowak, T.C., and Snyder, K.A. (1998). The impact of husbands' and wives' relative earnings on marital disruption. Journal of Marriage and the Family 60(3): 690-703. doi:10.2307/353538.

Henz, U. and Jonsson, J.O. (2003). Union Disruption in Sweden: Does Economic Dependency Inhibit Separation? International Journal of Sociology 33(1): 3-39.

Heuveline, P., Timberlake, J.M., and Furstenberg, F.F., Jr. (2003). Shifting Childrearing to Single Mothers: Results from 17 Western Countries. Population and Development Review 29(1): 47-71. doi:10.1111/j.1728-4457.2003.00047.x.

Hewitt, B. (2009). Which Spouse Initiates Marital Separation When There Are Children Involved? Journal of Marriage and the Family 71(2): 362-372. doi:10.1111/j.1741-3737.2009.00603.x.

Hewitt, B. and De Vaus, D. (2009). Change in the Association Between Premarital Cohabitation and Separation, Australia 1945-2000. Journal of Marriage and the Family 71(2): 353-361. doi:10.1111/j.1741-3737.2009.00604.x.

Hoem, J.M. (1997). Educational Gradients in Divorce Risks in Sweden in Recent Decades. Population Studies 51(1): 19-27. doi:10.1080/0032472031000149696.

Hoem, J.M. and Hoem, B. (1992). The Disruption of Marital and Non-Marital Unions in Contemporary Sweden. In: Trussell, J., Hankinson, R., and Tilton, J. (eds.). The Disruption of Marital and Non-Marital Unions in Contemporary Sweden. Oxford, England: Clarendon Press: 61-93.

Hohmann-Marriott, B. E. 2006. Shared beliefs and the union stability of married and cohabiting couples. Journal of Marriage and the Family 68 (4):1015-1028. doi:10.1111/j.1741-3737.2006.00310.x.

Jalovaara, M. (2001). Socio-economic status and divorce in first marriages in Finland 1991-93. Population Studies 55(2): 119-133. doi:10.1080/00324720127685.

Jalovaara, M. (2002). Socioeconomic differentials in divorce risk by duration of marriage. Demographic Research 7(16): 537-564. doi:10.4054/DemRes.2002.7.16. 
Jalovaara, M. (2003). The joint effects of marriage partners' socioeconomic positions on the risk of divorce. Demography 40(1): 67-81. doi:10.1353/dem.2003.0004.

Jensen, A.M. and Clausen, S. (2003). Children and family dissolution in Norway - The impact of consensual unions. Childhood 10(1): 65-81. doi:10.1177/0907568203010001004.

Kaestner, R. (1997) The effects of cocaine and marijuana use on marriage and marital stability. Journal of Family Issues 18(2): 145-173. doi:10.1177/0192 51397018002003.

Kalmijn, M. (1998). Intermarriage and Homogamy: Causes, patterns, trends. Annual Review of Sociology 24(August): 395-421. doi:10.1146/annurev.soc.24.1.395.

Kalmijn, M., de Graaf, P.M., and Janssen, J.P.G. (2005). Intermarriage and the risk of divorce in the Netherlands: The effects of differences in religion and in nationality, 1974-94. Population Studies 59(1): 71-85. doi:10.1080/0032472052000332719.

Kalmijn, M., de Graaf, P.M., and Poortman, A.-R. (2004). Interactions Between Cultural and Economic Determinants of Divorce in The Netherlands. Journal of Marriage and the Family 66(1): 75-89. doi:10.1111/j.1741-3737.2004.00006.x.

Kalmijn, M., Loeve, A., and Manting, D. (2007). Income dynamics in couples and the dissolution of marriage and cohabitation. Demography 44(1): 159-179. doi:10.1353/dem.2007.0005.

Kalmijn, M. and Poortman, A.-R. (2006). His or Her Divorce? The Gendered Nature of Divorce and its Determinants European Sociological Review 22(2): 201-214. doi:10.1093/esr/jci052.

Katzev, A.R., Warner, R.L., and Acock, A.C. (1994). Girls or Boys - Relationship of Child Gender to Marital Instability. Journal of Marriage and the Family 56(1): 89-100. doi: $10.2307 / 352704$.

Kaufman, G. (2000). Do gender role attitudes matter? Family formation and dissolution among traditional and egalitarian men and women. Journal of Family Issues 21(1): 128-144. doi:10.1177/019251300021001006.

Kiernan, K. (2004). Unmarried Cohabitation and Parenthood in Britain and Europe. Law \& Policy 26(1): 33-55. doi:10.1111/j.0265-8240.2004.00162.x.

Kiernan, K.E. (1986). Teenage Marriage and Marital Breakdown: A Longitudinal Study. Population Studies 40(1): 35-54. doi:10.1080/0032472031000141826. 
Kiernan, K.E. (2001). The Rise of Cohabitation and Childbearing outside Marriage in Western Europe. International Journal of Law, Policy \& the Family 15(1): 1-21. doi:10.1093/lawfam/15.1.1.

Kiernan, K.E. and Cherlin, A.J. (1999). Parental divorce and partnership dissolution in adulthood: Evidence from a British cohort study. Population Studies 53(1): 3948. doi:10.1080/00324720308068.

Kingston-Riechers, J. (2001). The association between the frequency of wife assault and marital dissolution in Canada. Journal of Population Economics 14(2): 351365. doi:10.1007/s001480000055.

Klijzing, E. (1992). "Weeding" in the Netherlands: First-Union Disruption among Men and Women Bron between 1928 and 1965. European Sociological Review 8(1): 53-10.

Kneip, T. and Bauer, G. (2009). Did Unilateral Divorce Laws Raise Divorce Rates in Western Europe? Journal of Marriage and the Family 71(3): 592-607. doi:10.1111/j.1741-3737.2009.00621.x.

Kposowa, A.J. (1998). The impact of race on divorce in the United States. Journal of Comparative Family Studies 29(3): 529-549.

Kraft, K. (2001). Unemployment and the separation of married couples. Kyklos: Internationale Zeitschrift für Sozialwissenschaften 54(1): 67-88.

Kravdal, Ø. (1988). The impact of first-birth timing on divorce: New evidence from a longitudinal analysis based on the central population register of Norway. European Journal of Population 4(3): 247-269. doi:10.1007/BF01796896.

Lehrer, E.L. (2004). Religion as a determinant of economic and demographic behavior in the United States. Population and Development Review 30(4): 707-726. doi:10.1111/j.1728-4457.2004.00038.x.

Lehrer, E.L. (2008). Age at marriage and marital instability: revisiting the BeckerLandes-Michael hypothesis Journal of Population Economics 21(2): 463-484. doi:10.1007/s00148-006-0092-9.

Lehrer, E.L. and Chiswick, C.U. (1993). Religion as a Determinant of Marital Stability. Demography 30(3): 385-404. doi:10.2307/2061647.

Lewin, A.C. (2005). The effect of economic stability on family stability among welfare recipients. Evaluation Review 29(3): 223-240. doi:10.1177/0193841X04272558. 
Li, J.-C.A. and Wu, L.L. (2008). No Trend in the Intergenerational Transmission of Divorce. Demography 45(4): 875-883. doi:10.1353/dem.0.0030.

Liefbroer, A.C. and Dourlejin, E. (2006). Unmarried Cohabitation and Union Stability: Testing the Role of Diffusion Using Data From 16 European Countries Demography 43(2): 203-221.

Lillard, L.A. (1993) Simultaneous equations for hazards. Journal of Econometrics $56(189-217$.

Lillard, L.A., Brien, M.J., and Waite, L.J. (1995). Premarital Cohabitation and Subsequent Marital Dissolution - a Matter of Self-Selection. Demography 32(3): 437-457. doi:10.2307/2061690.

Lillard, L.A. and Waite, L.J. (1993). A joint model of marital disruption and marital fertility. Demography 30(4): 653-681. doi:10.2307/2061812.

Liu, G. (2002). How premarital children and childbearing in current marriage influence divorce of Swedish women in their first marriages. Demographic Research 7(10): 389-406. doi:10.4054/DemRes.2002.7.10.

Lundberg, S. and Pollak, R.A. (1996). Bargaining and Distribution in Marriage. The Journal of Economic Perspectives 10(4): 139-158.

Lutz, W., Wils, A.B., and Nieminen, M. (1991). The Demographic Dimensions of Divorce - the Case of Finland. Population Studies 45(3): 437-453. doi: $10.1080 / 0032472031000145626$.

Lyngstad, T.H. (2004). The Impact of Parents' and Spouses' Education on Divorce Rates in Norway. Demographic Research 10(5): 122-142.

Lyngstad, T.H. (2006a). Does Community Context Have Important Bearings on the Divorce Rate? A Fixed-Effects Study of Twenty Norwegian First-Marriage Cohorts. VID Working Papers 06/2006. Vienna: Vienna Institute for Demography.

Lyngstad, T.H. (2006b). Why Do Couples with Highly Educated Parents Have Higher Divorce Risk? European Sociological Review 22(1): 49-60. doi:10.1093/esr/jci041.

Lyngstad, T.H. and Engelhardt, H. (2009). The influence of offspring's sex and age at parents' divorce on the intergenerational transmission of divorce, Norwegian first marriages 1980-2003. Population Studies 63(2): 173-185. doi:10.1080/00324720902896044. 
Manning, W.D., Smock, P.J. and Majumdar, D. (2004). The relative stability of cohabiting and marital unions for children. Population Research and Policy Review 23(2): 135-159. doi:10.1023/B:POPU.0000019916.29156.a7.

Martin, S.P. (2006). Trends in Marital Dissolution by Women's Education in the United States. Demographic Research 15(20): 537-560. doi:10.4054/DemRes. 2006.15.20.

Martin, T.C. and Bumpass, L.L. (1989). Recent Trends in Marital Disruption. Demography 26(1): 37-51. doi:10.2307/2061492

Mastekaasa, A. (1994). Psychological Well-Being and Marital Dissolution - Selection Effects. Journal of Family Issues 15(2): 208-228. doi:10.1177/0192513X94015002004.

Mauldon, J. (1992). Children's Risks of Experiencing Divorce and Remarriage: Do Disabled Children Destabilize Marriages? Population Studies 46(2): 349-362. doi:10.1080/0032472031000146276.

Mazur, A. and Michalek, J. (1998). Marriage, divorce, and male testosterone. Social Forces 77(1): 315-330. doi:10.2307/3006019.

McGue, M. and Lykken, D.T. (1992). Genetic Influence on Risk of Divorce. Psychological Science 3(6): 368-373. doi:10.1111/j.1467-9280.1992.tb00049.x.

McKinnish, T.G. (2004). Occupation, sex-integration, and divorce. American Economic Review 94(2): 322-325. doi:10.1257/0002828041301911.

Morgan, S.P., Lye, D.N., and Condran, G.A. (1988). Sons, Daughters, and the Risk of Marital Disruption. American Journal of Sociology 94(1): 110-129. doi:10.1086/228953.

Muszynska, M. (2008). Women's employment and union dissolution in a changing socio-economic context in Russia. Demographic Research 18(6): 181-204. doi:10.4054/DemRes.2008.18.6.

Muszynska, M. and Kulu, H. (2007). Migration and union dissolution in a changing socio-economic context: The case of Russia. Demographic Research 17(27): 803-820. doi:10.4054/DemRes.2007.17.27.

Najman, J.M., Vance, J.C., Boyle, F., Embleton, G., Foster, B., and Thearle, J. (1993). The Impact Of A Child-Death On Marital Adjustment. Social Science \& Medicine 37(8): 1005-1010. doi:10.1016/0277-9536(93)90435-7. 
Nixon, L.A. (1997). The Effect of Child Support Enforcement on Marital Dissolution. Journal of Human Resources 32(1): 159-181. doi:10.2307/146244.

Noack, T., Seierstad, A., and Weedon-Fekjær, H. (2005). A Demographic Analysis of Registered Partnerships (legal same-sex unions): The Case of Norway. European Journal of Population 21(1): 89-109. doi:10.1007/s10680-005-3626-z.

Oliver, L.E. (1999). Effects of a child's death on the marital relationship: A review. Omega-Journal Of Death And Dying 39(3): 197-227. doi:10.2190/1L3J-42VCBE4H-LFVU.

Ono, H. (1998). Husbands' and wives' resources and marital dissolution. Journal of Marriage and the Family 60(3): 674-689. doi:10.2307/353537.

Ono, H. (1999). Historical time and US marital dissolution. Social Forces 77(3): 969999. doi: $10.2307 / 3005968$.

Oppenheimer, V.K. (1997). Women's employment and the gain to marriage: the specialization and trading model. Annual Review of Sociology 23(1): 431-453. doi:10.1146/annurev.soc.23.1.431.

Ostermann, J., Sloan, F.A., and Taylor, D.H. (2005). Heavy alcohol use and marital dissolution in the USA. Social Science \& Medicine 61(11): 2304-2316. doi:10.1016/j.socscimed.2005.07.021.

Phillips, J.A. and Sweeney, M.M. (2005). Premarital cohabitation and marital disruption among White, Black, and Mexican American women. Journal of Marriage and the Family 67(2): 296-314. doi:10.1111/j.00222445.2005.00117.x.

Phillips, J.A. and Sweeney, M.M. (2006). Can differential exposure to risk factors explain recent racial and ethnic variation in marital disruption? Social Science Research 35(2): 409-434. doi:10.1016/j.ssresearch.2005.04.002.

Phillips, R. (1991). Untying the knot: A short history of divorce Cambridge: Cambridge University Press.

Poortman, A.-R. (2005). How work affects divorce - The mediating role of financial and time pressures. Journal of Family Issues 26(2): 168-195. doi:10.1177/0192513X04270228.

Poortman, A.-R. (2005). Women's work and divorce: a matter of anticipation? A Research Note. European Sociological Review 21(3): 301-309. doi:10.1093/esr/jci019. 
Poortman, A.-R. and Kalmijn, M. (2002). Women's Labor Market Position and Divorce in the Netherlands: Evaluating Economic Interpretations of the Work Effect. European Journal of Population 18(2): 175-202. doi:10.1023/ A:1015520411449.

Poortman, A.R. and Lyngstad, T.H. (2007). Dissolution risks in first and higher order marital and cohabiting unions. Social Science Research 36(4): 1431-1446. doi:10.1016/j.ssresearch.2007.02.005.

Power, C. and Estaugh, V. (1990). The Role of Family Formation and Dissolution in Shaping Drinking Behaviour in Early Adulthood. British Journal of Addiction 85(4): 521-530. doi:10.1111/j.1360-0443.1990.tb01672.x.

Presser, H.B. (2000). Nonstandard work schedules and marital instability. Journal of Marriage and the Family 62(1): 93-110. doi:10.1111/j.1741-3737.2000.00093.x.

Raley, R.K. and Wildsmith, E. (2004). Cohabitation and children's family instability. Journal of Marriage and the Family 66(1): 210-219. doi:10.1111/j.00222445.2004.00014.x-i1.

Reichman, N.E., Corman, H., and Noonan, K. (2004). Effects of Child Health on Parents' Relationship Status. Demography 41(3): 569-584. doi:10.1353/dem.2004.0026.

Rogers, S.J. (2004). Dollars, dependency, and divorce: Four perspectives on the role of wives' income. Journal of Marriage and the Family 66(1): 59-74. doi:10.1111/j.1741-3737.2004.00005.x.

Ross, H.L. and Sawhill, I.V. (1975). Time of Transition. The Growth of Families Headed by Women Washington, DC The Urban Institute.

Sander, W. (1992). Unemployment and Marital-Status in Great-Britain. Social Biology 39(3-4): 299-305.

Sayer, L.C. and Bianchi, S.M. (2000). Women's economic independence and the probability of divorce - A review and reexamination. Journal of Family Issues 21(7): 906-943. doi:10.1177/019251300021007005.

Schoen, R., Astone, N.M., Rothert, K., Standish, N.J., and Kim, Y.J. (2002). Women's employment, marital happiness, and divorce. Social Forces 81(2): 643-662. doi:10.1353/sof.2003.0019.

Schwab, R. (1998). A Child's Death and Divorce Risk. Dispelling the Myth. Death Studies 22(5): 445-468. doi:10.1080/074811898201452. 
Sobotka, T. and Toulemon, L. (2008). Changing family and partnership behaviour: Common trends and persistent diversity across Europe. Demographic Research 19(6): 85-138. doi:10.4054/DemRes.2008.19.6.

South, S.J. (1995). Do You Need to Shop around - Age at Marriage, Spousal Alternatives, and Marital Dissolution. Journal of Family Issues 16(4): 432-449. doi:10.1177/019251395016004002.

South, S.J. (2001a). The geographic context of divorce: Do neighborhoods matter? Journal of Marriage and the Family 63(3): 755-766. doi:10.1111/j.17413737.2001.00755.x.

South, S.J. (2001b). Time-dependent effects of wives' employment on marital dissolution. American Sociological Review 66(2): 226-245. doi:10.2307/2657416.

South, S.J. and Lloyd, K.M. (1995). Spousal Alternatives and Marital Dissolution. American Sociological Review 60(1): 21-35. doi:10.2307/2096343.

South, S.J., Trent, K. and Shen, Y. (2001). Changing Partners: Toward a Macrostructural-Opportunity Theory of Marital Dissolution. Journal of Marriage and the Family 63(3): 743-754. doi:10.1111/j.17413737.2001.00743.x.

Steele, F., Joshi, H., Kallis, C., and Goldstein, H. (2006). Changing compatibility of cohabitation and childbearing between young British women born in 1958 and 1970. Population Studies 60(2): 137-152. doi:10.1080/00324720600598009.

Steele, F., Kallis, C., Goldstein, H., and Joshi, H. (2005). The relationship between childbearing and transitions from marriage and cohabitation in Britain. Demography 42(4): 647-673. doi:10.1353/dem.2005.0038.

Steele, F., Kallis, C., and Joshi, H. (2006). The formation and outcomes of cohabiting and marital partnerships in early adulthood: the role of previous partnership experience. Journal of the Royal Statistical Society Series a-Statistics in Society 169(4): 757-779. doi:10.1111/j.1467-985X.2006.00420.x.

Svarer, M. (2004). Is your love in vain? Another look at premarital cohabitation and divorce. Journal of Human Resources 39(2): 523-535. doi:10.2307/3559025.

Svarer, M. (2007). Working late - Do workplace sex ratios affect partnership formation and dissolution? Journal of Human Resources 42(3): 583-595.

Svarer, M. and Verner, M. (2006). Do Children Stabilize Danish Marriages? Journal of Population Economics 21(2): 395-417. doi:10.1007/s00148-006-0084-9. 
Sweeney, M.M. and Phillips, J.A. (2004). Understanding racial differences in marital disruption: Recent trends and explanations. Journal of Marriage and the Family 66(3): 639-650. doi:10.1111/j.0022-2445.2004.00043.x.

Syse, A. and Kravdal, Ø. (2007). Does cancer affect the divorce rate? Demographic Research 16(15): 469-492. doi:10.4054/DemRes.2007.16.15.

Syse, A., Loge, J.H., and Lyngstad, T.H. (2010). Does childhood cancer affect parental divorce rates? A population-based study. Journal of Clinical Oncology 28(5): 872-877. doi:10.1200/JCO.2009.24.0556.

Teachman, J. (2002). Stability across cohorts in divorce risk factors. Demography 39(2): 331-352. doi:10.1353/dem.2002.0019.

Teachman, J. (2008). Complex life course patterns and the risk of divorce in second marriages. Journal of Marriage and the Family 70(2): 294-305. doi:10.1111/j.1741-3737.2008.00482.x.

Teachman, J.D. and Polonko, K.A. (1990). Cohabitation and Marital Stability in the United-States. Social Forces 69(1): 207-220. doi:10.2307/2579614.

Thomas, A. and Sawhill, I. (2002). For richer or for poorer: Marriage as an antipoverty strategy. Journal of Policy Analysis and Management 21(4): 587-599. doi:10.1002/pam.10075.

Thomson, E. and Colella, U. (1992). Cohabitation and Marital Stability - Quality or Commitment. Journal of Marriage and the Family 54(2): 259-267. doi: $10.2307 / 353057$.

Tjøtta, S. and Vaage, K. (2003). Union Disruption in Norway. International Journal of Sociology 33(1): 40-63.

Traag, T., Dronkers, J., and Vallet, L.-A. (2000). The Intergenerational Transmission of Divorce Risks in France. [unpublished manuscript]. Paper presented at the Conference of Research Committee 28 - Social Stratification of the International Sociological Association in Libourne, France. May 11-14, 2000: Publisher.

Trovato, F. (1993). Religious Disaffiliation and Divorce in Canada. Journal of Divorce \& Remarriage 20(1-2): 189-204.

Tzeng, J.M. and Mare, R.D. (1995). Labor-Market and Socioeconomic Effects on Marital Stability. Social Science Research 24(4): 329-351. doi:10.1006/ssre.1995.1013. 
Tzeng, M.-S. (1992). The Effects of Socioeconomic Heterogamy and Changes on Marital Dissolution for First Marriages. Journal of Marriage and the Family 54(3): 609-619. doi:10.2307/353246.

Udry, J.R. (1981). Marital alternatives and marital disruption. Journal of Marriage and the Family 43(4): 889-898. doi:10.2307/351345.

Udry, J.R. (1983). The marital happiness/disruption level by level of marital alternatives. Journal of Marriage and the Family 45(1): 221-222. doi:10.2307/351311.

van Poppel, F. and De Beer, J. (1993). Measuring the Effect of Changing Legislation on the Frequency of Divorce - the Netherlands, 1830-1990. Demography 30(3): 425-441. doi:10.2307/2061649.

Vignoli, D. and Ferro, I. (2009). Rising marital disruption in Italy and its correlates. Demographic Research 20(4): 11-36. doi:10.4054/DemRes.2009.20.4.

Wagner, M. and Weiss, B. (2006). On the Variation of Divorce Risks in Europe: Findings from a Meta-Analysis of European Longitudinal Studies. European Sociological Review 22(5): 483-500. doi:10.1093/esr/jcl014.

Waite, L.J. (1995). Does Marriage Matter? Demography 32(4): 483-507. doi:10.2307/2061670.

Waite, L.J. and Lillard, L.A. (1991). Children and Marital Disruption. American Journal of Sociology 96(4): 930-953. doi:10.1086/229613.

Walke, R. (2002). Twins or two single children:the influence of the multiplicity of the first birth on the divorce risk of Swedish women. Demographic Research 7(9): 379-390. doi:10.4054/DemRes.2002.7.9.

Walker, I. and Zhu, Y. (2006). Child support and partnership dissolution. Economic Journal 116(510): C93-C109. doi:10.1111/j.1468-0297.2006.01078.x.

Weiss, Y. and Willis, R.J. (1997). Match quality, new information, and marital dissolution. Journal of Labor Economics 15(1,2): S293-S329.

White, L.K. (1990). Determinants of Divorce - a Review of Research in the 80s. Journal of Marriage and the Family 52(4): 904-912. doi:10.2307/353309.

Wilson, S.E. and Waddoups, S.L. (2002). Good marriages gone bad: Health mismatches as a cause of later-life marital dissolution. Population Research and Policy Review 21(6): 505-533. doi:10.1023/A:1022990517611. 
Winship, C. and Morgan, S.L. (1999). The estimation of causal effects from observational data. Annual Review of Sociology 25: 659-706. doi:10.1146/annurev.soc.25.1.659.

Wolfers, J. (2006). Did Unilateral Divorce Laws Raise Divorce Rates? A Reconciliation and New Results. The American Economic Review 96(5): 1802-1820. doi:10.1257/aer.96.5.1802.

Wolfinger, N.H. (1999). Trends in the Intergenerational Transmission of Divorce. Demography 36(3): 415-420. doi:10.2307/2648064.

Wolfinger, N.H. (2003). Family structure homogamy: The effects of parental divorce on partner selection and marital stability. Social Science Research 32: 80-97. doi:10.1016/S0049-089X(02)00014-5.

Wolfinger, N.H. (2005). Understanding the Divorce Cycle. Cambridge, MA: Cambridge University Press. doi:10.1017/CBO9780511499616.

Wu, L. and Musick, K. (2008). Stability of Marital and Cohabiting Unions Following a First Birth. Population Research and Policy Review 27(6): 713-727. doi:10.1007/s11113-008-9093-6.

Zhang, Y. and Hook, J.V. (2009). Marital Dissolution Among Interracial Couples. Journal of Marriage and Family 71(1): 95-107. doi:10.1111/j.17413737.2008.00582.x. 
Lyngstad \& Jalovaara: Antecedents of union dissolution 